\title{
HUBUNGAN SIKAP ILMIAH DAN MOTIVASI BERPRESTASI DENGAN PERSEPSI SISWA TERHADAP MATA PELAJARAN KIMIA
}

\author{
Ayu Aneke Putri, Sulistyo Saputro*, dan Ashadi \\ Program Studi Pendidikan Kimia, FKIP,Universitas Sebelas Maret, Surakarta, Indonesia \\ *Keperluan korespondensi, telp : 081329196891, e-mail : sulistyo68@yahoo.com
}

\begin{abstract}
ABSTRAK
Tujuan penelitian ini adalah untuk mengetahui ada tidaknya hubungan antara sikap ilmiah dan motivasi berprestasi dengan persepsi siswa terhadap mata pelajaran kimia kelas X IPA 1 SMA Negeri 1 Ngemplak. Penelitian ini menggunakan metode korelasi, dengan cluster random sampling. Sampel terdiri dari 1 kelas. Data sikap ilmiah menggunakan angket, data motivasi berprestasi menggunakan angket, data persepsi siswa terhadap mata pelajaran kimia menggunakan angket, uji hipotesis menggunakan analisis korelasi dan regresi. Berdasarkan hasil penelitian dapat disimpulkan bahwa terdapat hubungan positif dan signifikan antara sikap ilmiah dan persepsi siswa terhadap mata pelajaran kimia dengan indeks korelasi 0,956, terdapat hubungan positif dan signifikan antara motivasi berprestasi dan persepsi siswa terhadap mata pelajaran kimia dengan indeks korelasi 0,895 , terdapat hubungan positif yang signifikan antara sikap ilmiah dan motivasi berprestasi dengan persepsi siswa terhadap mata pelajaran kimia yang ditunjukkan melalui hasil perhitungan analisis korelasi dan regresi dengan taraf signifikansi $5 \%$. Persamaan regresi linear yang diperoleh $Y=0,76 X_{1}+0.0044 X_{2}+122.8$ dan hasil $F_{\text {hitung }}=27,5>$ $\mathrm{F}_{\text {tabel }}=5,49$.
\end{abstract}

Kata Kunci: sikap ilmiah, motivasi berprestasi, persepsi siswa terhadap mata pelajaran kimia.

\section{PENDAHULUAN}

Pendidikan memegang peranan penting dalam menentukan masa depan dan kelangsungan hidup suatu bangsa. Melalui pendidikan akan dihasilkan manusia-manusia terdidik sebagai sumber daya manusia berkualitas yang akan berperan dalam pembangunan. Mengingat pentingnya peranan pendidikan, maka masalah pendidikan menjadi perhatian serius bangsa Indonesia. Pemerintah berusaha membentuk suatu sistem pendidikan yang berkualitas sehingga tujuan pendidikan nasional dapat tercapai. Sistem pendidikan ini disesuaikan dengan perkembangan masyarakat serta perkembangan ilmu pengetahuan dan teknologi agar bangsa Indonesia mampu sejajar dengan bangsa-bangsa lain di dunia [1].

Ilmu kimia merupakan ilmu yang diperoleh dan dikembangkan berdasar- kan eksperimen untuk mencari jawaban dari pertanyaan apa, mengapa, dan bagaimana gejala-gejala alam. Mata pelajaran kimia di SMA mempelajari tentang zat yang meliputi komposisi, struktur dan sifat, transformasi, dinamika dan energetika zat yang melibatkan ketrampilan dan penalaran. IImu kimia merupakan produk (pengetahuan kimia yang berupa fakta, teori, prinsip, hukum) temuan saintis dan proses (kerja ilmiah), oleh sebab itu dalam penilaian dan pembelajaran kimia harus memperhatikan karakteristik ilmu kimia sebagai produk dan proses [2].

Satu hal yang perlu diperhatikan dalam pembelajaran adalah faktor-faktor internal siswa seperti kemampuan awal, motivasi, kreaktifitas, berpikir kritis, kemampuan memori, sikap ilmiah, dan lain-lain. Selain beberapa faktor internal di atas ada beberapa faktor internal lain yang diduga berhubungan terhadap 
persepsi siswa terhadap mata pelajaran kimia yang di dalamnya memerlukan banyak perhitungan dan juga faktor internal sikap siswa terhadap kecenderungan untuk bertindak dan termotivasi dalam memecahkan masalah secara sistematis melalui langkah ilmiah. Oleh karena itu sikap ilmiah dan motivasi berprestasi diduga sebagai faktor internal yang berhubungan dengan persepsi terhadap mata pelajaran kimia.

Sikap ilmiah merupakan salah satu faktor internal yang dapat mempengaruhi prestasi belajar. Dengan sikap ilmiah yang tinggi akan mendorong seseorang untuk selalu ingin tahu pada hal-hal yang baru dan hal-hal yang ada di sekitarnya. Dari rasa ingin tahu tersebut merangsang siswa untuk lebih memperhatikan kemudian menimbulkan keinginan siswa untuk memberikan respon pada apa yang telah diamatinya. Sikap ilmiah yang digunakan pada penelitian adalah teliti, jujur, disiplin, menghargai pendapat orang lain, menyampaikan pendapat/ide, sikap, ingin tahu, bekerja sama, dan kritis [3].

Sekolah merupakan pusat pendidikan dan pengajaran dan sering dikatakan bahwa masa depan suatu bangsa terletak di bidang pendidikannya. Dalam bidang pendidikan, terdapat hubungan yang erat antara sikap ilmiah siswa dan keberhasilan belajar. Berkaitan dengan belajar, Melton menjelaskan bahwa motivasi yang terpenting dalam pendidikan adalah motivasi berprestasi dan merupakan stimulus kuat dalam belajar. Lebih lanjut McClelland menyatakan bahwa motivasi berprestasi merupakan motivasi yang paling penting dalam berbagai situasi belajar dengan orientasi tujuan pada pencapaian kesuksesan atau kegagalan [4]. Kaufman mengatakan bahwa terdapat keterkaitan sikap ilmiah siswa di sekolah dengan efek belajar yang dipengaruhi oleh motivasi terutama motivasi berprestasi [5].

Persepsi sebagai salah satu faktor internal siswa merupakan bagian yang tak terpisahkan dengan respon alat indera terhadap stimulus yang dihadapinya. Stimulus ini dapat beraneka ragam bentuknya dan stimulus yang berhubungan dengan ilmu kimia terkait dengan respon indera terhadap kejadian alam. Di hamparan alam semesta dengan gejala keunikan dan keteraturan, stimulus yang berupa gejala dapat direspon dengan cepat cenderung dapat meningkatkan motivasi belajar siswa. Motivasi ibaratnya sebagai niat seseorang untuk bertindak atau suatu dorongan dalam diri manusia untuk mencapai tujuan. Mengingat kajian kimia bersifat fisis, maka motivasi berprestasi siswa terhadap objek-objek tertentu erat kaitannya dengan timbulnya persepsi siswa terhadap ilmu kimia. Selain itu, halhal yang dirasa siswa terhadap mata pelajaran kimia akan mempengaruhi persepsi siswa terhadap ilmu kimia, di mana bila persepsinya baik, maka prestasi yang dicapai tentunya lebih baik.

Berdasarkan latar belakang yang telah diuraikan diatas, penulis tertarik mengadakan penelitian tentang "Hubungan Sikap IImiah dan Motivasi Berprestasi dengan Persepsi Siswa Terhadap Mata Pelajaran Kimia".

\section{METODE PENELITIAN}

Penelitian ini menggunakan metode korelasi. penelitian korelasional adalah penelitian yang akan melihat hubungan antara variabel atau beberapa variabel dengan variabel lain. Rancangan penelitian menggunakan analisis regresi dan korelasi. Untuk lebih jelasnya rancangan penelitian tercantum pada Tabel 1.

Tabel 1. Rancangan Penelitian

\section{Sampel}

\begin{tabular}{lll}
\hline Angket & Angket & Angket Persepsi \\
Sikap & Motivasi & Siswa terhadap \\
Ilmiah & Berprestasi & Mata Pelajaran \\
Siswa & Siswa & Kimia
\end{tabular}

Analisis Korelasi dan Regresi

Populasi dalam penelitian ini adalah siswa kelas X SMA Negeri 1 Ngemplak tahun pelajaran 2009/2010. Pada tahun ajaran tersebut, kelas X SMA Negeri 1 Ngemplak terdiri dari 10 kelas. Teknik pengambilan sampel pada 
penelitian ini adalah teknik cluster random sampling. Pada penelitian ini, peneliti mengambil sampel dalam bentuk kelas tunggal yaitu peneliti menentukan satu kelas sebagai sampel dari keseluruhan kelas $X$ yang ada di SMA Negeri 1 Ngemplak.

Jenis metode yang dipilih dalam pengumpulan data, tentunya harus sesuai dengan sifat dan karakteristik penelitian yang dilakukan. Dalam penelitian ini, teknik pengumpulan data yang digunakan adalah angket untuk ketiga variabel yaitu sikap ilmiah, motivasi berprestasi dan persepsi siswa terhadap mata pelajaran kimia.

Teknik analisis angket afektif menggunakan: (1) Uji validitas, untuk mengukur validitas digunakan rumus formula Gregorry dan (2) Uji reliabilitas, untuk mengetahui tingkat reliabilitas digunakan rumus alpha, hasil uji coba reliabititas, angket afektif dinyatakan reliable dengan harga reliabilitas sebesar 0,954 untuk angket afektif.

Teknik analisis data menggunakan uji analisis korelasi dan regresi yang mensyaratkan data normal, linear dan independen. Untuk menguji apakah sampel penelitian dari populasi distribusi normal atau tidak digunakan metode Lilliefors, untuk menguji ada tidaknya hubungan fungsional dan keberartian korelasi digunakan uji linearitas dan keberartian regresi, sedangkan untuk mengetahui apakah antara masingmasing variabel bebas saling bebas maka digunakan uji independensi rumus korelasi product moment. Analisis korelasi dan regresi dilakukan dengan menguji hipotesis pertama dan kedua yang menyatakan ada tidaknya hubungan antara sikap ilmiah dengan persepsi siswa terhadap mata pelajaran kimia dan motivasi berprestasi dengan persepsi siswa terhadap mata pelajaran kimia, terakhir dilakukan uji hipotesis ketiga yang menyatakan ada tidaknya hubungan antara sikap ilmiah dan motivasi berprestasi dengan persepsi siswa terhadap mata pelajaran kimia. Besarnya kontribusi variabel-variabel bebas terhadap variabel terikat ditentukan dengan melakukan analisis kontribusi berdasarkan hasil uji hipotesis pertama, kedua dan ketiga

\section{HASIL DAN PEMBAHASAN}

Dalam penelitian ini digunakan teknik analisis regresi dan korelasi. Salah satu syarat teknik ini yang dapat diterapkan adalah populasi sampel harus normal pada distribusi frekuensinya. Untuk mengetahui apakah syarat tersebut telah terpenuhi, maka dilakukan uji normalitas. Dalam penelitian ini digunakan uji normalitas Lilliefors. Uji ini bertujuan untuk mengetahui apakah sampel dalam penelitian ini terdistribusi normal atau tidak. Rangkuman hasil uji normalitas dapat dilihat pada Tabel 2 . Dari tabel tersebut menunjuk-kan bahwa taraf signifikansi $\alpha=0,05$ harga Lmaks lebih besar dari L tabel. Dalam hal ini Ho diterima sehingga dapat disimpulkan bahwa sampel berasal dari populasi yang berdistribusi normal.

Uji linearitas dan keberartian regresi menunjukkan adanya hubungan fungsional antara sikap ilmiah dengan persepsi siswa terhadap mata pelajaran kimia dan motivasi berprestasi dengan persepsi siswa terhadap mata pelajaran kimia di mana koefisien regresinya berarti. Rangkuman Uji Linearitas dan Keberartian Regresi dapat dilihat pada Tabel 3.

Uji independensi digunakan untuk menyelidiki ada tidaknya ketergantungan antara variabel-variabel bebas. Bila di antara variabel tersebut tidak terdapat hubungan, maka variabel-variabel tersebut bersifat independen atau saling lepas. Rangkuman hasil uji independensi dapat dilihat pada Tabel 4.

Uji hipotesis pertama dan kedua dilakukan dengan analisis korelasi product moment. Hipotesis pertama menyatakan bahwa terdapat korelasi antara sikap ilmiah dengan persepsi siswa terhadap mata pelajaran kimia, dengan bentuk korelasi positif. Dari perhitungan didapatkan harga $r_{x 1 y}=$ 0,956 . Harga ini dikonsultasikan dengan $r_{\text {tabel }(30 ; 0,05)}=0,361$, hasilnya : $0,956>$ 0,361 , sehingga hipotesis pertama dinyatakan dapat diterima. Artinya terdapat korelasi yang positif antara 
sikap ilmiah dengan persepsi siswa terhadap mata pelajaran kimia, siswa kelas X IPA 1 SMAN 1 Ngemplak. Bila dikonsultasikan pada tabel interpretasi harga $r$, maka hubungan antara sikap ilmiah dengan persepsi siswa terhadap mata pelajaran kimia adalah hubungan yang tinggi. Kemudian pada uji keberartian koefisien korelasi didapatkan hargastatistik uji $\mathrm{t}=5,058$, sementara harga $t_{\text {tabel }}=1,701$. Dengan demikian $t_{\text {hitung }}>t_{\text {tabel }}$. Ini berarti bahwa koefisien korelasinya signifikan atau berarti.

Tabel 2. Rangkuman Uji Hasil Uji Normalitas

\begin{tabular}{llccc}
\hline No & \multicolumn{1}{c}{ Variabel } & $\begin{array}{c}\text { Harga Liliefors } \\
\text { Hitung }(\mathrm{L})\end{array}$ & $\begin{array}{c}\text { Harga Liliefors Tabel } \\
\left(\mathrm{L}_{0.05 ; 30}\right)\end{array}$ & Keterangan \\
\hline 1. & Sikap Ilmiah & 0,2154 & 0,161 & Normal \\
2. & Motivasi Berprestasi & 0,1716 & 0,161 & Normal \\
3. & Persespsi siswa terhadap & 0,1734 & 0,161 & Normal \\
& mata pelajaran kimia & & & \\
\hline
\end{tabular}

Tabel 3. Rangkuman Uji Linearitas dan Keberartian Regresi

\begin{tabular}{|c|c|c|c|c|c|}
\hline Sampel & Uji & F hitung & $\begin{array}{l}\text { F tabel } \\
(0,05)\end{array}$ & Kriteria & Keputusan \\
\hline \multirow{2}{*}{$X_{1} Y$} & $\begin{array}{l}\text { Uji Linearitas } \\
\text { Regresi }\end{array}$ & $F_{1}=0,610$ & 2,65 & $\mathrm{~F}_{1}<\mathrm{F}_{\text {tabel }}$ & Linear \\
\hline & $\begin{array}{c}\text { Uji Keberartian } \\
\text { Regresi }\end{array}$ & $F_{2}=30,04$ & 4,2 & $\mathrm{~F}_{2}>\mathrm{F}_{\text {tabel }}$ & Berarti \\
\hline \multirow{2}{*}{$\mathrm{X}_{2} \mathrm{Y}$} & $\begin{array}{l}\text { Uji Linearitas } \\
\text { Regresi }\end{array}$ & $F_{1}=0,087$ & 2,53 & $\mathrm{~F}_{1}<\mathrm{F}_{\text {tabel }}$ & Linear \\
\hline & $\begin{array}{c}\text { Uji Keberartian } \\
\text { Regresi }\end{array}$ & $F_{2}=28,107$ & 4,2 & $F_{2}>F_{\text {tabel }}$ & Berarti \\
\hline
\end{tabular}

Tabel 4. Rangkuman hasil Uji Independensi

\begin{tabular}{ccccc}
\hline No & Hubungan & r hitung & $r$ tabel & Keterangan \\
\hline 1. & $X_{1}$ dan $X_{2}$ & 0,305 & 0,361 & Independen \\
\hline
\end{tabular}

Hipotesis kedua menyatakan bahwa terdapat korelasi antara motivasi berprestasi dengan persepsi siswa terhadap mata pelajaran kimia, dengan bentuk korelasi positif. Dari perhitungan didapatkan harga $r_{x 2 y}=0,895$. Harga ini dikonsultasikan dengan $r_{\text {tabel }(30 ; 0,05)}=$ 0,361 , hasilnya : $0,895>0,361$. Dari harga $r$ yang positif tersebut, terdapat korelasi yang positif antara motivasi berprestasi dengan persepsi siswa terhadap mata pelajaran kimia siswa kelas X IPA 1 SMAN 1 Ngemplak. Bila dikonsultasikan pada tabel interpretasi harga $r$, maka hubungan antara motivasi berprestasi dengan persepsi siswa terhadap mata pelajaran kimia adalah hubungan yang tinggi. Kemudian pada uji keberartian koefisien korelasi didapatkan harga statistik uji $t=4,735$, sementara harga $t_{\text {tabel }}=1,701$. Dengan demikian $t_{\text {hitung }}>t_{\text {tabel. }}$. Ini berarti bahwa koefisien korelasinya signifikan atau berarti.

Hipotesis ketiga menyatakan terdapat korelasi antara sikap ilmiah dan motivasi berprestasi dengan persepsi siswa terhadap mata pelajaran kimia siswa kelas X IPA 1 SMAN 1 Ngemplak tahun pelajaran 2017/2018. Untuk menguji hipotesis III yaitu terdapat hubungan positif antara sikap ilmiah $\left(\mathrm{X}_{1}\right)$ dan motivasi berprestasi $\left(X_{2}\right)$ siswa secara bersama dengan persepsi siswa terhadap mata pelajaran kimia (Y) digunakan analisis dua prediktor pada uji linearitas $X_{1}$ dan $X_{2}$ terhadap $Y$. Dari hasil perhitungan diperoleh harga koefisien korelasi ganda, $R=0,953$. Kemudian didapatkan harga statistik uji $F_{\text {hitung }}=$ 
27,5, sementara harga $F_{\text {tabel }}=5,49$. Karena $F_{\text {hitung }}>F_{\text {tabel }}$, berarti koefisien korelasi ganda antara sikap ilmiah $\left(X_{1}\right)$ dan motivasi berprestasi $\left(X_{2}\right)$ siswa dengan persepsi siswa terhadapmata pelajaran kimia $(\mathrm{Y})$ signifikan atau berarti.Peran variabel bebas terhadap terbentuknya regresi linear antara variabel-variabel bebas terhadap variabel terikat dapat diketahui melalui analisis kontribusi. Besarnya sumbangan relatif dan sumbangan efektif yang diberikan masing-masing variabel bebas diperoleh dari harga $\mathrm{JK}_{\text {regresi }}$ yang telah diketahui. Rangkuman analisis kontribusi dapat dilihat pada Tabel 5 .

Tabel 5. Sumbangan Variabel Bebas Terhadap Variabel Terikat (Persepsi Siswa Terhadap Mata Pelajaran Kimia (Y) pada Model Regresi Dengan Variabel Sikap Ilmiah $\left(\mathrm{X}_{1}\right)$ dan Motivasi Berprestasi $\left(\mathrm{X}_{2}\right)$

\begin{tabular}{ccc}
\hline Variabel Bebas & Sikap Ilmiah, X1 (\%) & Motivasi Berprestasi, X2 (\%) \\
\hline Sumbangan Relatif & 99,31 & 0,69 \\
Sumbangan Efektif & 90,22 & 0,63 \\
\hline
\end{tabular}

Berdasarkan hasil uji hipotesis pertama dengan analisis korelasi product moment Karl Pearson mendapatkan hasil berupa harga $r_{x 1 y}=0,956$. Harga ini dikonsultasikan dengan $r_{\text {tabel(30;0,05) }}=$ 0,361 , hasilnya : $0,956>0,361$, sehingga ada korelasi yang positif antara sikap ilmiah dengan persepsi siswa terhadap mata pelajaran kimia pada siswa kelas $X$ IPA 1 SMAN 1 Ngemplak. Ini menunjukkan bahwa semakin baik atau semakin tinggi sikap ilmiah yang dimiliki oleh siswa, maka semakin besar kecenderungan siswa tersebut untuk memiliki persepsi yang tinggi terhadap mata pelajaran kimia. Sebaliknya jika semakin rendah sikap ilmiah yang dimiliki oleh siswa, maka semakin besar kecenderungan siswa untuk memiliki persepsi terhadap mata pelajaran kimia.

Hasil uji hipotesis pertama mengenai hubungan sikap ilmiah dengan persepsi siswa terhadap ilmu kimia menunjukkan adanya hubungan yang signifikan dan positif. Hal ini karena siswa yang siswa yang memiliki sikap ilmiah yang tinggi memiliki persepsi yang positif dan tinggi terhadap pembelajaran kimia, sehingga mendorong antusias siswa mengikuti pelajaran kimia untuk mendapat prestasi yang baik. Sikap ilmiah memiliki hubungan positif dengan persepsi siswa terhadap pelajaran kimia karena sikap ilmiah yang dimiliki siswa mampu mendorong mereka untuk lebih tertarik dan terlibat dalam pembelajaran sains sehingga pemahaman konsep siswa juga menjadi lebih baik. Sementara itu siswa yang memiliki sikap ilmiah rendah cenderung tidak antusias dan sulit mengikuti proses pembelajaran sehingga sulit menguasai materi dalam pembelajaran kimia. Hal ini menjelaskan bahwa sikap ilmiah siswa memberikan hubungan positif secara signifikan dengan persepsi terhadap mata pelajaran kimia.

Berdasarkan hasil uji hipotesis kedua dengan analisis korelasi product moment Pearson mendapatkan hasil berupa harga $r_{x 2 y}=0,895$. Harga ini dikonsultasikan dengan $r_{\text {tabel }(30 ; 0,05)}=$ 0,361 , hasilnya : $0,895>0,361$, sehingga ada korelasi positif antara motivasi berprestasi dengan persepsi siswa terhadap mata pelajaran kimia kelas $X$ IPA 1 SMAN 1 Ngemplak. Ini menunjukkan bahwa semakin baik atau semakin tinggi motivasi berprestasi yang dimiliki oleh siswa, maka semakin besar kecenderungan siswa tersebut untuk memiliki persepsi yang tinggi terhadap mata pelajaran kimia. Sebaliknya jika semakin rendah motivasi berprestasi yang dimiliki oleh siswa, maka semakin besar kecenderungan siswa untuk memiliki persepsi yang rendah terhadap mata pelajaran kimia.

Motivasi berprestasi merupakan salah satu faktor internal yang ikut menentukan keberhasilan dalam belajar. Persepsi yang baik ikut menentukan keberhasilan siswa dalam pembelajaran. Motivasi berprestasi adalah kondisi 
fisiologis dan psikologis yang terdapat dalam diri siswa yang mendorongnya untuk melakukan aktivitas tertentu guna berprestasi setinggi mungkin.

Menurut Winkel, terdapat beberapa ciri siswa yang memiliki motivasi berprestasi tinggi, diantaranya keinginan untuk bekerja dan berusaha sendiri serta menemukan penyelesaian sendiri, keinginan kuat untuk maju dan mencapai taraf keberhasilan, orientasi ke masa depan dan keuletan dalam belajar walaupun menghadapi rintangan [6].

Hasil pengujian hipotesis ketiga menyatakan bahwa terdapat korelasi antara sikap ilmiah dan motivasi berprestasi dengan persepsi siswa terhadap mata pelajaran kimia X IPA 1 SMAN 1 Ngemplak tahun pelajaran 2017/2018. Sikap ilmiah memberikan sumbangan relatif sebesar 99,31\% dengan sumbangan efektif sebesar $90,22 \%$, sedangkan motivasi berprestasi memberikan sumbangan relatif sebesar $0,69 \%$ dengan sumbangan efektif sebesar 0,63\%.

Adanya sumbangan sikap ilmiah dan motivasi berprestasi dalam penelitian ini membuktikan bahwa persespsi siswa terhadap mata pelajaran kimia memiliki korelasi dengan faktorfaktor internal. Sikap ilmiah dan motivasi berprestasi merupakan faktor internal yang bersifat non-intelektif. Faktor internal non-intelektif adalah merupakan faktor dari dalam diri siswa yang berupa unsur-unsur kepribadian tertentu seperti sikap, kebiasaan, minat, kebutuhan, motivasi, emosi dan penyesuaian diri.

Persepsi siswa terhadap mata pelajaran kimia tidak hanya berkorelasi dengan faktor internal saja, akan tetapi juga dengan faktor eksternal, yaitu faktor yang berasal dari luar diri siswa. Yang termasuk faktor ini adalah faktor sosial yang terdiri atas lingkungan keluarga, lingkungan sekolah, lingkungan masyarakat dan lingkungan kelompok; faktor budaya seperti adat istiadat, ilmu pengetahuan dan teknologi serta kesenian; faktor lingkungan fisik seperti fasilitas rumah, fasilitas belajar dan iklim; serta faktor lingkungan spiritual atau keamanan.
Berdasarkan uraian di atas, diketahui bahwa sikap ilmiah dan motivasi berprestasi mempunyai korelasi yang positif signifikan dengan persepsi siswa terhadap mata pelajaran kimia kelas X IPA 1 SMAN 1 Ngemplak. Sikap ilmiah dan motivasi berprestasi perlu dikembangkan untuk membentuk persepsi yang positif dan tinggi dalam pembelajaran kimia karena dapat mendorong seorang siswa melakukan usaha semaksimal mungkin dalam mencapai prestasi yang setinggitingginya. Menjadi kewajiban guru untuk dapat meningkatkan sikap ilmiah dan motivasi berprestasi siswa melalui penciptaan kondisi belajar dan strategi mengajar yang tepat.

\section{KESIMPULAN}

Dari hasil penelitian dapat disimpulkan bahwa (1) Terdapat korelasi antara sikap ilmiah dengan persepsi siswa terhadap mata pelajaran kimia kelas X IPA 1 SMAN 1 Ngemplak tahun ajaran 2017/2018, dengan indeks korelasi 0,956, bentuk korelasi positif, semakin tinggi sikap ilmiah maka persepsi siswa terhadap mata pelajaran kimia semakin baik; (2) Terdapat korelasi antara motivasi berprestasi dengan persepsi siswa terhadap mata pelajaran kimia kelas X IPA 1 SMAN 1 Ngemplak tahun ajaran 2017/2018, dengan indeks korelasi 0,895, bentuk korelasi positif, semakin tinggi motivasi berprestasi, maka persepsi siswa terhadap mata pelajaran kimia semakin baik; (3) Terdapat hubungan positif yang signifikan antara sikap ilmiah dan motivasi berprestasi dengan persepsi siswa terhadap mata pelajaran kimia kelas X IPA 1 SMAN 1 Ngemplak tahun ajaran 2017/2018. Hal ini ditunjukkan dengan harga $F_{\text {hitung }}=27,5>F_{\text {tabel }}=5,49$. Besarnya SR dan SE sikap ilmiah terhadap persepsi siswa dalam mata pelajaran kimia adalah 99,31 \% dan $90,22 \%$. Sedangkan SR dan SE motivasi berprestasi terhadap persepsi siswa dalam mata pelajaran kimia adalah 0,69 $\%$ dan $0,63 \%$ 
UCAPAN TERIMA KASIH

Bapak Drs. Sunarno, M.Pd., selaku Kepala SMAN 1 Ngemplak, yang telah memberikan ijin untuk melaksanakan penelitian, Bapak St.Kristiyanto, S.Pd., selaku guru mata pelajaran Kimia SMAN 1 Ngemplak, yang telah memberi pengarahan dan bantuan selama berjalannya penelitian serta siswa-siswi kelas X IPA 1 SMAN 1 Ngemplak yang telah membantu penelitian ini.

\section{DAFTAR RUJUKAN}

[1] Notoatmojo, Soekidjo. 2003. Pengembangan Sumber Daya Manusia. Jakarta: Rineka Cipta
[2] Keenan. 1986. Kimia Untuk Universitas Edisi 6 Jilid I. Jakarta: Erlangga

[3] Baharudin, B. 2005. Pendekatan Keterampilan Proses. Jakarta : PT. Gramedia.

[4] McClelland, David C. 1953. The achievement motive. New York: Appleton-Century-Crofts.

[5] Kaufman, R, \& Thomas, S. 1980. Evaluation without Fear. New York: New Viewpoints 